\title{
ДЕМОГРАФИЧЕСКОЕ БУДУЩЕЕ КИТАЯ
}

\author{
ЮЛИЯ СЕЛИВЕРСТОВА
}

\begin{abstract}
Статья посвящена прогнозу развития демографической ситуачии в КНР до 2030 г. Дается характеристика текущих демографических изменений, таких как стремительное старение населения, снижение рождаемости, половой дисбаланс, трудовая миграџия из села в город, активный проиесс урбанизации. Показано, что острота сущеествующих социильных вопросов во многом обусловлена политикой ограничения рождаемости в стране, проводившейся на протяжении 35 лет. Распространение малодетности и иенностей современной городской среды значительно изменили форму семьи и ее функции. При сохранении сущчествующих тенденций население Китая 6 размере 1,4 млрд человек через 8 лет исчерпает потенциал к росту, начнется естественная убыль. При увеличении числа пожильх людей и высокой продолжительности жизни трудоспособное население будет сокращуаться, еще сильнее уменьшится количество детей в возрасте до 14 лет. Окончание действия демографического дивиденда для экономического развития КНР сопряжено с ростом социальной напряженности. В ближайшие годы значительно возрастет нагрузка на систему городской прописки, сочиильного обеспечения и здравоохранения. Для эффективного противодействия нарастающему кризису правительству страны необходимо уделить повышенное внимание решению проблем сельских жителей, реформированию системь пенсионного и медицинского страхования, укреплению института семьи, мерам по поддержке семей с детьми.
\end{abstract}

Ключевые слова: население КНР, уменьшение семьи, старение, падение рождаемости, урбанизация, трудовая миграция, политика ограничения рождаемости, демографический дивиденд.

\section{ВВЕДЕНИЕ}

Глобальные демографические перемены в мире наряду с усиливающейся неравномерностью экономического развития отдельных регионов, миграционными вызовами и нарастающими экологическими проблемами, оказывают огромное влияние на развитие мирового сообщества. Крупнейшая экономика мира сильнее других оказалась подвержена подобным изменениям. И если вопрос внешней миграции для Китая не стоит остро, то темпы старения и урбанизации беспрецедентны в истории. Современные проблемы народонаселения КНР хорошо коррелируют с проблемами, присущими демографической ситуации в развитых странах на соответствующей стадии демографического перехода. Большинство этих стран давно завершили демографический переход, их экономические и социальные институты функционируют десятилетиями в условиях низкой рождаемости и смертности, следовательно и активного старения населения. Китай же лишь с начала XXI века столкнулся с этими проблемами. Всего за 50 лет КНР успела пройти сразу две фазы демографического перехода, на что другие страны потратили сто лет (Баженова 2019: 103). Переход от высоких показателей рождаемости и смертности к низким стал важным фактором в развитии страны.

ЮЛИЯ АНДРЕЕВНА СЕЛИВЕРСТОВА (yukupriyanova@hse.ru), НАЦИОНАЛЬНЫЙ ИССЛЕДОВАТЕЛЬСКИЙ УНИВЕРСИТЕТ «ВЫСШАЯ ШКОЛА ЭКОНОМИКИ», РОССИЯ.

СТАТЬЯ ПОСТУПИЛА В РЕДАКЦИЮ В АПРЕЛЕ 2020 Г. 
Китайское экономическое чудо не могло бы случиться, не получи страна значительный демографический дивиденд. Большая доля трудоспособного населения при низком проценте пожилых людей в совокупности со снижением рождаемости на протяжении 60 лет стимулировала развитие страны. Однако время бонусов закончилось. Привычное восприятие КНР как «мастерской мира» и страны с самой дешевой рабочей силой более не актуально. При средней оплате труда в размере 2,5 \$ в час в 2019 г. Китай уже сейчас не может выдержать конкуренцию на рынке дешевой рабочей силы с такими странами как Индия, Бангладеш, Вьетнам, Индонезия. При этом эксперты прогнозируют рост заработной платы в производственной сфере в КНР к 2030 г. почти до 4 \$ в час (Passport analysis 2018a), что в сочетании со стремительным сокращением доли трудоспособного населения не оставит возможности для дальнейшего развития с опорой на собственный рынок рабочей силы (в указанных странах уровень оплаты почти не изменится, оставшись на уровне $1 \$$ ).

Население страны активно трансформируется с точки зрения как количественных, так и качественных характеристик. И городские, и сельские жители сталкиваются с проблемами, которые раньше не стояли так остро для общества. В данной статье рассматриваются тенденции отдельных демографических процессов, происходящих в настоящий момент в КНР, в их тесной взаимосвязи с факторами социально-экономического развития, таким как: внутренняя трудовая миграция, урбанизация, старение населения и уменьшение размеров семьи. Показано, каким образом падение рождаемости, рост продолжительности жизни и половой дисбаланс будут в ближайшее десятилетие формировать новый облик китайского общества.

Быстрые трансформации в стране с самым большим в мире населением вызывают большой интерес в научном сообществе не только внутри Китая, но и за его пределами. В ряде работ последних двух десятилетий российских и китайских ученых подробно исследованы различные аспекты социальной политики Китая (Ли Вэй 2003; Назарова, Серова 2010; Киреев 2011). Однако тема прогнозирования демографического развития до настоящего момента остается гораздо менее изученной. В фундаментальном труде Е.С. Баженовой по вопросам населения КНР отдельный раздел посвящен стратегическим целям китайского правительства в области демографического регулирования в начале XXI века (Баженова 2010). Недавняя работа, исследующая региональную дифференциацию демографического развития провинций Китая, указывает на наличие дивергенции по ряду демографических показателей после 2010 г., что создает новые вызовы для устойчивого развития страны в ближайшем будущем (Kalabikhina, Shatalova, Fang Lieming 2020: 97). Также стоит выделить несколько исследований российских авторов, посвященных будущим сценариям социального развития страны. Ученые согласны с мнением китайских экспертов о том, что Китай, возможно, «постареет раньше, чем разбогатеет», однако говорят о богатом опыте, накопленном страной в вопросах социального регулирования (Виноградов и др. 2014: 13,14). Другой коллектив исследователей, прибегая к математическому моделированию, рассматривал два вероятных сценария развития демографической ситуации в зависимости от сохранения или отмены политики «одна семья - один ребенок». Авторы выделяют половой дисбаланс и рост пенсионной нагрузки как наиболее острые будущие проблемы (Коротаев, Зинькина 2014: 37). В свете уже 
свершившейся с 2016 г. полной отмены политики «одного ребенка» особый интерес представляет недавняя статья китайского исследователя Фан Лемина, посвященная анализу эффекта новых мер китайского правительства по стимулированию рождаемости с опорой на двухдетную семью (Fang Lieming 2019). Подводя промежуточные итоги работы властей в области деторождения, автор указывает на недостаточность мер, называя новую политику «переходной» (Fang Lieming 2019: 43).

На данный момент население Китая остается самым многочисленным в мире и продолжает расти. Каким же будет китайское общество в будущем? Во многом ответ на этот вопрос связан с демографической ситуацией ближайших десятилетий. По скорректированным прогнозам ООН, к 2030 г. число жителей КНР должно увеличиться с нынешних 1 млрд 433 млн до 1 млрд 464 млн человек (United Nations... 2019: 17). В среднесрочном прогнозе демографического развития до 2030 г., опубликованном Госсоветом КНР в 2016 г. ${ }^{1}$, точные цифры не называются. Однако китайские госструктуры, как и аналитики ООН, говорят о достижении абсолютного максимума и начале естественной убыли населения до наступления 2030 г., называя период с 2021 по 2030 г. «критическим поворотным моментом демографического развития». В Национальном плане выделены наиболее острые проблемы народонаселения, которые должны решить китайские власти за 15 лет. В их число входят борьба с бедностью, провинциальная и межрегиональная трудовая миграция, повышение рождаемости, создание инклюзивной среды для одиноких стариков и др.

\section{УМЕНЫШЕНИЕ РАЗМЕРОВ СЕМЬИ}

В ноябре 2020 г. состоялась седьмая перепись населения КНР. По опыту предшествующей переписи 2010 г. можно ожидать, что первые результаты ее станут доступны широким кругам общественности примерно спустя полгода. Свежие данные о народонаселении, безусловно, дадут властям основания для корректировки 14-го пятилетнего плана развития (2021-2025 гг.). С высокой долей вероятности потребуется внести изменения и в имеющиеся среднесрочные и долгосрочные планы. Подобные прогнозы находятся в тесной взаимосвязи с количеством граждан определенного возраста и социального статуса. Демографические переменные не только являются результатом политики государства, но и отражают морально-этические ценности, субъективное поведение граждан, их отношение к браку и деторождению. А институт семьи в Китае сейчас претерпевает сильнейшую трансформацию. Это не может не сказываться на точности китайских и зарубежных прогнозов, касающихся будущего страны.

По информации ГСУ КНР, на конец 2019 г. население страны (не включая Макао, Гонконг, Тайвань) превысило отметку в 1,4 млрд. Огромная впечатляющая цифра скрывает за собой большие противоречия современного китайского общества. Общемировые тренды,

\footnotetext{
${ }^{1}$ Guojia renkou fazhan guihua (2016-2030 nian) (Национальный план демографического развития (20162030 гг.)). URL: http://www.gov.cn/zhengce/content/2017-01/25/content_5163309.htm (дата обращения: 09.07.2020).
} 
такие как увеличение числа одиноких людей, нуклеарные семьи, отложенное материнство, расширяющийся средний класс с более высокими доходами в равной степени характерны и для Китая (Passport analysis 2018b). Однако на фоне падения рождаемости и активного старения населения данные тенденции несут в себе большую угрозу для стабильности социально-экономического положения самой многочисленной нации в мире.

Традиционный уклад семьи, где дети являлись основной опорой для родителей в старости, претерпел кардинальные изменения за 35 лет проведения политики ограничения рождаемости «одна семья - один ребенок». И хотя плановая демографическая политика была значительно скорректирована с 2016 г., активный процесс урбанизации, распространение малодетного поведения и ценностей потребительской культуры продолжают активно менять лицо китайской семьи. В начале XXI века размер семьи был примерно 3,44 человека, а спустя десятилетие, по данным 6-й Всекитайской переписи населения, 400 млн китайских домохозяйств в среднем состояли из 3,1 человека (Баженова 2018а: 98). В 2014 г. в крупных городах более половины семей ограничивались 1-2 членами (Passport statistics 2019). Как ожидается, в течение 10 лет число домохозяйств, состоящих из одного человека, должно вырасти еще на 39\% (Passport analysis 2019a).

Китайские семьи становятся не только меньше, но и старше. Постепенно увеличивается возраст вступления в брак, а также возраст рождения первого ребенка (27 лет в 2014 г., 29 лет в 2019 г.) (Passport statistics 2019). Растет число разводов при сокращении числа браков (5 лет назад заключалось 10 браков, сейчас всего 8 на 1000 человек) (Passport statistics 2019). В ІІІ квартале 2019 г. был зафиксирован рекордно высокий уровень разводов - 3,1млн разводов против 7,13 млн браков ${ }^{2}$. Все больше людей предпочитают жить поодиночке. Помимо субъективных причин нежелания вступать в брак, в китайском обществе существуют и объективные преграды для семейной жизни. Традиционное предпочтение потомков мужского пола при возможности рождения всего одного малыша в семье привело к серьезному перекосу в половой структуре населения КНР. Китай стал своего рода страной холостяков-мужчин. По данным 2010 г. число мужчин превосходило число женщин на 35 млн (Почагина 2016: 189), а в 2019 г. разница достигла 37,5 млн. И хотя в обществе постепенно отмирает традиционное предпочтение рождения сыновей, проблема полового дисбаланса по инерции будет еще усугубляться. На данный момент в Китае мальчиков (в возрасте 0-14 лет) на 16 млн больше, чем девочек (Passport statistics 2019), а это значит, что в ближайшие десятилетия ситуация нехватки невест сохранится.

\section{ПАДЕНИЕ РОЖДАЕМОСТИ}

Самой острой проблемой, связанной с изменением семейного уклада современных китайцев, является уменьшение числа детей. Уже десятилетия в Китае наблюдается тревожно низкий коэффициент суммарной рождаемости $(\text { КСР })^{3}$, который для сохранения

\footnotetext{
2019 nian renkou chushenglv dadie beihou jiujing shuomingle shenme? (Что именно стоит за резким падением рождаемости в 2019 году). URL: https://baijiahao.baidu.com/s?id=1661937065475034592\&wfr=spider\&for=pc (дата обращения: 16.04.2020).

${ }^{3}$ Коэффициент суммарной рождаемости показывает, сколько детей рожает в среднем одна женщина за всю свою жизнь с 15 до 50 лет при условии, что на всем протяжении репродуктивного периода жизни данного
} 
стабильного населения должен находиться на уровне 2,1 (Киреев 2015: 15). Китай, безусловно, не стоит особняком на фоне остального мира. Коэффициент рождаемости во всех развитых странах, за исключением Израиля (Passport analysis 2018b), уже упал ниже необходимой для воспроизведения нации отметки. Уникальность проблемы КНР состоит в том, что низкая рождаемость является не только следствием естественных процессов в обществе. Значительные перекосы в половом и возрастном составе населения - результат многолетней искусственной меры по ограничению прироста населения «одна семья - один ребенок».

Острота проблемы также состоит в том, что рождаемость в современном китайском обществе упала уж слишком сильно. По данным переписи населения 2010 г., СКР в крупных городах был 0,88 при среднекитайском в 1,18. В отдельных провинциях КНР сохранялся более высокий уровень фертильности, что связано с особыми мерами в прежней плановой политике по отношению к малым народам. Однако в общем можно говорить о сближении регионов по данному показателю и даже о наличии эффекта «наверстывания»: провинции с более высоким уровнем рождаемости имеют более высокие темпы ее падения, чем регионы с изначально более низким уровнем СКР (Kalabikhina, Shatalova, Fang Lieming 2020: 87).

Китай, очевидно, попал в «ловушку низкой рождаемости». Согласно теории «ловушки», новые поколения граждан страны, вырастая в окружении малодетных или бездетных семей, придерживаются аналогичного репродуктивного поведения, предпочитают иметь мало детей или не иметь их совсем (Lutz, Skirbekk, Testa 2006; Фахрисламова 2015: 105). В такую ситуацию попадают страны с СКР менее 1,3. Согласно концепции, «ловушка» заключается еще и в том, что в малодетном обществе начинают работать самоусиливающиеся механизмы, которые могут приводить к еще большему снижению рождаемости. Страна уже не может вернуться на уровень естественного воспроизведения нации. И хотя политика «одного ребенка», которая проводилась в стране с начала 1980-х годов, в 2013 г. была отменена частично, а с 2016 г. полностью, бум появления вторых детей так и не случился. Поколения китайцев 80-х и 90х годов, которые росли при тотальной кампании по ограничению рождаемости, в своем репродуктивном поведении ориентируются по-прежнему на однодетную семью, не желая рожать второго ребенка. Часть молодых семей решает вовсе не заводить детей. На 2016 г. количество бездетных семей в Китае превысило 600 тыс. (Веселова 2018: 1459).

Сразу после объявления старта новой политики «одна семья - два ребенка» китайские эксперты ожидали значительного роста рождаемости в 13-й пятилетке (20162020 гг.) за счет увеличения доли вторых детей. Итоги 2016 и 2017 г. не в полной мере оправдали расчеты, хотя и наблюдался рост. А следующие 2 года стали вообще провальными. Вместо бэби-бума Китай установил рекорды низкой рождаемости. Показатель 2018 г. составил 15,23 млн новорожденных, что оказалось практически на 2 млн меньше данных 2017 г. и стало самым низким с 1961 г., периода Великого китайского голода (Сивинцева 2019: 54). Поколение 80-х под влиянием послаблений в плановом

поколения возрастные коэффициенты рождаемости в каждой возрастной группе остаются неизменными на уровне расчетного периода. 
деторождении быстро удовлетворило свою потребность в рождении второго ребенка в период с 2013 по 2017 г. А поколение 90-х оказалось на практике не готово к рождению второго ребенка, что привело к новому рекорду низкой рождаемости в 2019 г. - 14, 6 млн детей (Passport statistics 2019). Эффект от перехода к политике двухдетной семьи оказался слишком краткосрочным ${ }^{4}$. Нежелание рожать детей, отсутствие возможности позволить себе их воспитание не позволили достигнуть заданных властями показателей (Fang Lieming 2019: 43). Ситуация дополнительно осложняется из-за ежегодного уменьшения числа рожениц в КНР. За период 12-го пятилетнего плана (2011-2015 гг.) количество женщин детородного возраста в стране ежегодно снижалось на 3,5 млн, а к моменту наступления 13-й пятилетки эта цифра достигла 5 млн 5 .

Завершение эпохи политики «одного ребенка» явилось важным событием для будущей демографической картины страны. По официальным китайским прогнозам, переход к двухдетной семье будет способствовать смягчению ряда негативных тенденций в области народонаселения, в перспективе даст стране на 30 млн больше рабочих рук и на $2 \%$ уменьшит долю пожилых людей к середине века. В «Национальном плане развития населения на 2016-2030 гг.» говорится о росте коэффициента суммарной рождаемости до 1,8 ребенка на женщину (Fang Lieming 2019: 40-41). Западные эксперты считают такие ожидания избыточно оптимистичными. По прогнозам аналитиков компании Euromonitor International, коэффициент суммарной рождаемости в Китае к 2030 г. составит всего 1,2 ребенка на женщину при среднем показателе в Азиатско-Тихоокеанском регионе 1,9 (Passport analysis 2019b).

Осознавая остроту проблем последнего десятилетия, китайские власти активно работают над углублением реформ в области политики народонаселения. С 2018 г. ведется работа над формированием нового проекта Гражданского кодекса, в котором будут устранены все упоминания о контроле над рождаемостью. Но речи о полной отмене плановой политики деторождения все же пока не идет. В Китае на данный момент подавляющему числу семей позволено иметь лишь по два ребенка.

\section{СТАРЕНИЕ НАСЕЛЕНИЯ}

Население Земли стремительно стареет. В 2018 г., впервые в истории, число пожилых людей превысило число детей в возрасте до 5 лет. На мировой карте появляется все больше "старых" стран (по классификации ООН более 7\% населения в них составляют люди в возрасте 65 лет и старше). Китай стремительными темпами ворвался в группу таких стран и с каждым годом отвоевывает в нем новые позиции по уровню старения. Сверхнизкий уровень рождаемости в сочетании с растущей продолжительностью жизни ускоряют

\footnotetext{
${ }^{4} 2019$ nian renkou chushenglv dadie beihou jiujing shuomingle shenme? (Что именно стоит за резким падением рождаемости в 2019 году). URL: https://baijiahao.baidu.com/s?id=1661937065475034592\&wfr=spider\&for=pc (дата обращения: 16.04.2020).

5 "Shisanwu" jisheng guihua: nianjun renkou zenmezhang 900 wan 2016 nian shangwei "dabiao" (План по контролю рождаемости в 13-й пятилетке: среднегодовой прирост населения в 2016 году составил 9 млн человек, что все еще не достигает необходимых показателей). URL:

http://m.21jingji.com/article/20170208/3dcf3772f2aed67561a1ca105ae60d7a.html (дата обращения: 22.04.2017).
} 
старение китайской нации, что сближает Китай с наиболее развитыми странами мира. Социальные трансформации КНР, происходящие в последние 10 лет, были характерны для стран Западной Европы начала 1970-х годов (Акимов 2015: 10). Запад уже 50 лет успешно решает вопросы, которые встали перед китайскими политиками совсем недавно. На данный момент из 703 млн стариков Земли (Щербакова 2019) 167,6 млн проживает в Китае (Passport statistics 2019). Это каждый четвертый уже сейчас, а что ждет страну через десятилетие? И почему именно для Китая старение является столь болезненной проблемой?

Оставаясь государством с самым многочисленным населением на планете, КНР располагает огромным потенциалом для развития благодаря большому проценту трудоспособного населения (люди в возрасте 15-64 года составляют почти 71\%). При этом относительно мала численность групп в детских возрастах, что дает экономике преимущества в условиях низкого коэффициента демографической нагрузки. Данный коэффициент показывает соотношение населения детских и пожилых возрастов к общей массе людей трудоспособного возраста. В 2014 г. этот показатель составлял всего 37 на 100 граждан трудоспособного возраста (Passport statistics 2019) при среднемировом уровне в 53 (Щербакова 2014). За 5 лет коэффициент увеличился до 41, и в ближайшем будущем он будет только расти, так как пожилых китайцев будет становиться все больше, а людей, вступающих в трудоспособный возраст, меньше. Эффект от действия демографического дивиденда для КНР уже практически исчерпан (Баженова 2019: 110), не за горами времена тяжкого социального бремени.

Проблем добавляют и особенности еще не завершенной пенсионной реформы в Китае. До начала XXI века для большинства граждан, по сути, не существовало системы пенсионного страхования. Активное реформирование социального обеспечения началось после 1997 г., но сложный процесс растянулся на десятилетия. С 2014 г. реформа пенсионного обеспечения вошла в новую фазу, основная ее идея заключается в создании трехуровневой системы формирования пенсии, состоящей из обязательной распределительной части, накопительного финансирования из Пенсионного фонда и личных добровольных накоплений (Сюй Яньли 2017: 81). При этом вплоть до 2015 г. существовала и отдельная льготная система для государственных служащих и бюджетных работников, которым не нужно было совершать пенсионные отчисления, право на субсидируемую государством пенсию по старости они получали автоматически. Такое положение дел создавало определенное неравенство в обществе. Согласно официальным данным, в 2015 г. в Китае только 262 млн человек активно формировали пенсионные накопления. Позднее был принят новый Пенсионный план, призванный уравнять частную и государственную системы (Сюй Яньли 2017: 81-82). Потребуется не одно десятилетие, чтобы китайские пенсионеры начали получать социально уравненные, более справедливые выплаты. Нынешние пожилые граждане, которые не совершали отчисления на личный счет в течение жизни, а их работодатели не платили ежемесячные взносы в Пенсионный фонд, на данном этапе получают пенсию «переходного периода». И если не брать в расчет бывших госслужащих, то ежемесячные выплаты от государства среднему пенсионеру весьма скудны, совершенно не достаточны для покрытия минимальных нужд. Особенно плачевная ситуация в сельской местности (Ван Цзинтин 2019: 61,63). По данным 2017 г. в среднем только 31\% от общей численности трудовых 
ресурсов в Китае имели право на государственное пенсионное обеспечение любого вида (Сюй Яньли 2017: 78). Как же выживают старики в КНР? Традиционно роль пенсионного фонда играл институт семьи. Забота о пожилых людях являлась естественной обязанностью их детей. По данным опросов населения 2005 г., поддержка семьи являлась основным источником дохода для более чем половины людей старше 65 лет, проживающих в городах. В сельской местности эта цифра была еще более значительной (Сюй Яньли 2017: 78). Обязанность заботиться о стареющих родителях и бабушках с дедушками постепенно превращается в тяжкое бремя, так как двое супругов, не имеющие братьев и сестер, вынуждены содержать четверых своих стареющих родителей, а возможно, и более старшее поколение (Ван Цзинтин 2019: 64).

В Китае пенсионный возраст для мужчин составляет 60 лет, для женщин 50-55 лет, что достаточно рано в сравнении со среднемировыми показателями (средний возраст выхода на пенсию не доходит до 55 лет (Антропов, Середа 2017: 14)). Уже сейчас каждый шестой житель страны вышел за пределы трудоспособного возраста (Passport statistics 2019). При этом продолжительность жизни во всех регионах страны активно увеличивается с середины 1990-х гг. (Kalabikhina, Shatalova, Fang Lieming 2020: 91). В условиях дальнейшего роста этого показателя и сокращения рождаемости китайское общество столкнется с еще большим давлением на работающее население. За последние 5 лет в Китае его количество уменьшилось почти на 6 млн (Passport statistics 2019). И данная тенденция набирает обороты. За 10 лет произойдет сокращение рабочей силы еще на 40 млн (Passport analysis 2018a) - с 71 до 65\% от общей численности населения. Почти на четверть сократится когорта возраста 20-29 лет, в то время как число граждан в возрасте 70-79 лет вырастет на 80\%. Все это потребует значительных расходов на сферу социального обеспечения при сокращении общего числа молодежи, которая могла бы заботиться о стариках и выступать налогоплательщиками (Passport analysis 2019b). Сохранится рост продолжительности жизни (78,4 года к 2030 г.), что станет дополнительным вызовом для бюджета страны. С одной стороны, больше денег потребуется на выплату пособий для пожилых людей. В пенсионной системе уже сейчас существует проблема неравномерности темпов роста доходов и расходов фондов основного пенсионного страхования (Сунь Фу 2017: 172-173). Если тенденция будет продолжена, это может стать бременем для государственных финансов. По данным 2019 г. общий дефицит пенсионной системы КНР составил 3,5 трлн долларов (Росляков, Старцева 2019: 390). С другой стороны, появится большая нагрузка на систему здравоохранения, так как увеличится число людей, страдающих ожирением, диабетом, раком, сердечными заболеваниями (Passport analysis 2019b). По прогнозам, в период между 2000 и 2040 г. в стране смертность от сердечнососудистых заболеваний вырастет в 3 раза (Сюй Яньли 2017: 78). По подсчетам, у жителей Китая в ближайшие 4 года прогнозируется более чем 30\%-ный рост потребительских расходов на медицину и товары для здоровья, что связано с появлением большего числа людей, страдающих различными заболеваниями (Passport analysis 2019a). 


\section{УРБАНИЗАЦИЯ}

Еще 8 лет назад Китай был страной с преобладанием сельских жителей. Активный процесс урбанизации, характерный для всех регионов страны, за несколько десятилетий привел к росту городского населения в 2019 г. до 60,6 \% (848, 5 млн человек) ${ }^{6}$ (Kalabikhina, Shatalova, Fang Lieming 2020: 91). А уже к 2030 г. стремительно меняющаяся КНР ожидает увеличения числа горожан до 68\% (Passport analysis 2019). По ряду оценок показатель может достигнуть и $70 \%$, при среднемировом показателе $61 \%$ (Passport analysis 2018b), а число городских жителей может превысить 1 млрд человек (Островский 2013: 41).

Увеличение числа горожан неизбежно ведет к изменению образа жизни, дальнейшему снижению рождаемости и популяризации «одиночества». Размер семьи и коэффициент суммарной рождаемости в городах всегда ниже, чем в селах. Огромная трудовая миграция из деревень в более крупные центры либо между городами разных провинций уже не одно десятилетие является экономической, социальной и демографической проблемой КНР. Сельские жители (с преобладанием мужчин) в поисках заработка вынуждены на длительные сроки покидать свои домохозяйства - около $60 \%$ мигрантов - молодые люди в возрасте до 30 лет (У Яао 2015: 240). В деревне остаются неполные семьи, пожилые родители и малолетние дети под присмотром родственников (Почагина 2016: 184). Это меняет половозрастную структуру сельского населения, ухудшает возможность социальной адаптации младшего поколения, общую атмосферу в семьях. По данным последней переписи населения Китая 2010 г., число жителей, проживающих не по месту постоянной регистрации более 6 месяцев в году, составляло 260,9 млн человек (Понкратова, Тракова 2014: 110). В 2017 г. их число достигало 286 млн это каждый пятый житель страны (OECD 2019: 92), который вместе с супругом или в одиночку покидает родной дом с целью заработка. Подавляющее большинство таких мигрантов являются сельскими жителями, переезжающими в города в пределах родной провинции. Функционирующая в стране система регистрации по месту проживания (hukou sistem), созданная еще в маоистскую эпоху с целью предотвращения неконтролируемой миграции в города, сейчас устарела, не отвечает реалиям китайского общества (Ван Лили 2020: 34). Наличие городской прописки открывает доступ к социальному обеспечению и бесплатному начальному и среднему образованию детей. Отсутствие же ее у приезжих из сельской местности или городов других провинций порождает в среде мигрантов изоляцию, дискриминацию и затрудняет социальную интеграцию (У Яао 2015: 239). Существующая система прописки по ряду причин не позволяет мигрировать в города полными семьями. Более того, ребенок, рожденный в городе в семье людей с сельской пропиской, «наследует» деревенскую регистрацию своих родителей, остается исключенным из системы городского социального обеспечения (Ван Лили 2020: 35). Тем самым трудовые мигранты не имеют стимулов переезжать в города семьями, оставляют детей на попечении родственников, воспринимают свой городской статус как вынужденный, временный. Количество оставшихся без родителей детей в селах (люшоу

\footnotetext{
${ }^{6} 2019$ nian zhongguo zongrenkou shouci tupo14yi (В 2019 году население Китая впервые превысило 1,4 млрд). URL: http://finance.sina.com.cn/stock/stockzmt/2020-02-06/doc-iimxyqvz0597622.shtml (дата обращения: 10.04.2020).
} 
эртун) растет год от года, в 2018 г. эта цифра составила 70 млн (у 43\% таких детей оба родителя уехали в город) (Инь Шаша 2019: 51). В будущем ожидается еще больший отток трудоспособного населения из сельской местности, а значит, вопрос «оставленных детей» встанет острее.

Увеличение городского населения несет Китаю ряд вызовов. Масштабный приток крестьян в города потребует от государства обеспечивать полноценные условия проживания, образования, медицинского обслуживания. Трудовая миграция также оказывает и существенное воздействие на традиционные ценности и формы семейной жизни (Инь Шаша 2019: 53). При этом многие эксперты зачастую говорят о положительных сторонах этого процесса, указывая, что именно урбанизация должна стать ключевой мерой в борьбе с замедлением экономического роста страны. Она подтолкнет к росту сферы промышленности и услуг в городах второй и третьей линии (классификация, принятая внутри страны), чья экономика выступит новым драйвером развития, перехватив инициативу у традиционных мегаполисов. В ближайшие 10 лет среди 61 крупного города КНР прирост населения именно в городах второй и третьей линии составит до $89 \%$, что связано с целенаправленным упрощением властями получения городской прописки. Появятся уникальные города «с нуля». Уже разработаны масштабные проекты по созданию совершенно новых экологичных высокотехнологичных центров, например Новой зоны Сюн'ань в 100 км к юго-западу от Пекина (Passport analysis 2018b). Такие проекты призваны разгрузить нынешние перенаселенные мегаполисы, где число жителей все равно продолжит расти, но уже не такими темпами. По прогнозам, к 2030 г. население Гуанчжоу, Шэньчженя, Тяньцзиня превысит 16 млн человек. Пекин продолжит расти, достигнет 25 млн, и практически догонит Шанхай - самый густонаселенный город Поднебесной (Passport analysis 2019b), в котором уже несколько лет проводится политика по сдерживанию роста числа жителей. По плану правительства население этого крупнейшего мегаполиса к 2035 г. не должно превысить отметку в 25-27 млн человек (24,2 млн в 2018 г.), что не помешает ему сохранить свое нынешнее пятое место в рейтинге самых густонаселенных городов мира (Passport analysis 2018b).

Таким образом, уже через 10 лет двое из трех граждан КНР будут проживать в городах. Рост нынешних мегаполисов - городов первой линии - затормозится, на передовые позиции выйдут города второй и третьей линии. Урбанизация, стимулируя развитие новых отраслей хозяйства, заберет ресурсы у деревень, что может негативно отразиться на развитии сельского хозяйства и уровне жизни крестьян. Будущее китайского села выглядит весьма неопределенным в таких условиях. Помимо этого, увеличение числа горожан способно усилить и другие существующие сейчас в стране демографические проблемы, о которых было сказано выше.

\section{ЗАКЛЮЧЕНИЕ}

На данном этапе развития Китай достиг передовых экономических показателей, твердо отстаивает свое место на международной арене. Дипломатия мягкой силы и грандиозные региональные и континентальные проекты не оставляют сомнений в том, что КНР планирует оставаться глобальным лидером надолго. Эксперты всего мира активно следят 
за тем, как власти страны собираются преобразовывать Поднебесную, чьи города (за исключением западных регионов) все еще задыхаются от ядовитых выбросов, в «Прекрасный Китай» с голубым небом и зелеными равнинами.

Во многом достижение всех намеченных глобальных целей в развитии страны будет определяться успешным решением острых демографических вопросов, таких как стремительное старение населения при росте продолжительности жизни, устойчивое снижение рождаемости, половой дисбаланс, миграция сельского населения в города, изменение семейного уклада. Китай в ближайшие 30 лет претерпит огромную трансформацию; с каким знаком произойдут грядущие изменения, зависит во многом от корректности выбранной социально-экономической политики, реформирования системы прописки и социального страхования.

Население Китая плавно, но бесповоротно идет к естественной убыли, старению нации и нехватке людей трудоспособного возраста. В ближайшие 6 лет ожидается, что страна потеряет звание самой многонаселенной в мире, уступив место Индии (Passport analysis 2019b). Исторический максимум будет достигнут в 2028-2030 гг. (Passport analysis $2019 b)$, составит 1,46 млрд человек, затем КНР вступит в период отрицательных темпов прироста населения. Далее число жителей будет постоянно сокращаться и к 2050 г. вернется к нынешнему уровню в 1,4 млрд (United Nations... 2019: 17; Баженова 2018b: 111). По сути, число жителей КНР через 30 лет не изменится. Страна будет так же населена, как и сейчас. Но важны именно качественные изменения. Ключевой вопрос: как быстро будет увеличиваться диспропорция в разных возрастных группах и расти коэффициент демографической нагрузки. Для устойчивого социально-экономического развития страны большое значение будет играть каждый выигранный год или каждый отвоеванный процент.

По прогнозам через 10 лет Китай станет 41-ой в мире страной по уровню старения со средним возрастом жителя 42,5 года (Passport analysis 2019b). К 2050 г. когорта людей старше 60 лет достигнет полумиллиарда (Баженова 2018b:113) и каждый третий житель страны будет пожилым человеком. От того, насколько правительству удастся в ходе реформ обеспечить достойную пенсию старикам, во многом будет зависеть социальная стабильность и экономическое благополучие в стране, играющей ключевую роль в общемировом развитии.

\section{ЛИТЕРАТУРА}

Акимов А.В. (2015). Прогноз численности мирового населения до 2050 г. и трудосберегающие технологии. Восточная аналитика, 5, 9-26.

Антропов Р.В., Середа А.В. (2017). Право на трудовую пенсию по старости в современном Китае: проблемы реализации. В Лавров А.Ю. (Ред.), Актуальные проблемы развития КНР в прочессе ее регионализащии и глобализаџии (сс. 13-20). Чита: Забайкальский государственный университет.

Баженова Е.С. (2010). 1300000. Население Китая: стратегия развития и демографической политики. М.: Форум. 
Баженова Е.С. (2018b). Социально-демографическое развитие КНР. В Лузянин С.Г. (Ред.), Китайская Народная Республика: политика, экономика, культура. 2017-2018 (сc. 109119). М.: Издательство «Форум».

Баженова Е.С. (2018а). Китайская семья в условиях новой демографической политики. В Островский А.В. (Ред.), 13-я пятилетка (2016 - 2020 гz.) - важнейший этап построения в Китае общества малого благоденствия "сяокан" (сс. 97-109). М.: ФГБУН ИДВ РАН.

Баженова Е.С. (2019). Население Китая: новые тенденции в эпоху модернизации и экономических реформ. Проблемы Дальнего Востока, 5(1), 101-111. DOI: https://doi.org/10.31857/S013128120007131-5

Ван Лили (2020). Пути и формы совершенствования миграции крестьян в города в Китае. Медицина. Сочиология. Философия. Прикладные исследования, 2, 34-38.

Ван Цзинтин (2019). Бюджет пожилых людей в Китае: стратегии формирования. Общество: сочиология, психология, педагогика, 6(62), 61-66.

DOI: https://doi.org/10.24158/spp.2019.6.9

Веселова Л.С. (2018). Изменение статуса женщин в современном Китае: новые вызовы и возможности. Ученые записки Казанского университета. Серия Гуманитарные науки, $160(6), 1455-1465$.

Виноградов А.В. и др. (2014). Сценарии развития Китая до 2050 г. Восточная аналитика, 4, 11-15.

Инь Шаша (2019). Дети деревенских мигрантов в Китае: исследование проблем социализации. Общество: социология, психология, педагогика, 2(58), 50-54. DOI: $10.24158 / \mathrm{spp} .2019 .2 .8$

Киреев А.А. (2015). Изменения демографической политики Китая. Ученые записки Комсомольского-на-Амуре государственного технического университета, 2(2), 15-17.

Киреев А.А. и др. (2011). Современный Китай. Социально-экономическое развитие, национальная политика, этнопсихология. M.: URSS.

Коротаев А.В., Зинькина Ю.В. (2014). Математическое моделирование и сценарное прогнозирование демографического будущего КНР. Восточная аналитика, 4, 36-41.

Ли Вэй (2003). Развитие населения и семейно-демографическая политика в Китае и России: Oпыт сравнительного анализа. М.: Макс Пресс.

Назарова Р.Ф., Серова В.Д. (2010). Демографическая политика КНР: история и современность. Вестник Амурского государственного университета. Серия: Гуманитарные науки, 50, 42-49.

Островский А.В. (2013). Экономика КНР в 2030 году: проблемы и перспективы (как относиться к прогнозу экономического развития КНР, сделанному центром изучения положения в стране университета Цинхуа). В Доклады ИДВ РАН, 2012 (сс. 29-50). М.: ФГБУН ИДВ РАН.

Понкратова Л.А., Тракова Е.В. (2014). Внутренняя миграция в Китае: что показала перепись населения 2010 года. В Понкратова Л.А., Забияко А.А. (Ред.), Россия $u$ Китай: новый вектор развития сочиально-экономического сотрудничества (сс. 109116). Благовещенск: Амурский государственный университет.

Почагина О.В. (2016). Деформация семейных связей как угроза социальной стабильности в КНР. В Лавров А.Ю. (Ред.), Актуальные проблемы развития КНР в прочессе ее 
регионализащчии и глобализаџии (сс. 181-193). Чита: Забайкальский государственный университет.

Росляков А.А., Старцева С.В. (2019). Сравнительно-правовой анализ пенсионных систем РФ и КНР. Modern science, 12(1), 388-391.

Сивинцева О.В. (2019). Пронаталистский поворот в Китае: возврат к традиционным семейным ценностям или новая реальность? Вестник Пермского университета. Политология, 13, 3, 54-67. DOI: 10.17072/2218-1067-2019-3-54-67

Сунь Фу (2017). Экономико-правовые основы развития пенсионной системы Китая. Экономика: вчера, сегодня, завтра, 7, 2A, 171-185.

Сюй Яньли (2017). Демографические аспекты развития системы пенсионного обеспечения КНР. Труд и сочиальные отношения, 3, 76-83.

У Яао (2015). Социальная интеграция китайских внутренних мигрантов: условия жизни внутренних мигрантов (agricultural to nonagricultural) и мигрантов рабочих. Вестник Московского университета. Серия 18. Сочиология и политология, 4, 235-240.

Фахрисламова Р.Т. (2015). Низкая рождаемость: теории и подходы к объяснению. Вестник Южно-Российского государственного технического университета. Серия: Сочиально-экономические науки, 2, 101-109.

Щербакова Е.М. (2014). Демографическая нагрузка снизилась до минимального уровня, но в ближайшие годы начнет возрастать. Демоскоn Weekly, 601-602. URL: http://www.demoscope.ru/weekly/2014/0601/barom04.php

Щербакова Е.М. (2019). Население мира по оценкам ООН пересмотра 2019 года. Демоскоп Weekly, 821-822. URL: http://www.demoscope.ru/weekly/2019/0821/barom06.php

Fang Lieming (2019). Will China's "Two-child in one family" policy to spur population growth work? Population and Economics, 3 (2), 36-44. DOI: https://doi.org/10.3897/popecon.3.e37962

Kalabikhina I., Shatalova E., Fang Lieming (2020). Demographic situation in China: convergence or divergence? BRICS Journal of Economics, 1 (1), 81-101. DOI: http://doi.org/10.38050/2712-7508-2020-6

Lutz W., Skirbekk V., Testa M.R. (2006). The Low-Fertility Trap Hypothesis: Forces that May Lead to Further Postponement and Fewer Births in Europe. Vienna Yearbook of Population Research, 4. (Postponement of Childbearing in Europe), 167-192. DOI:10.1553/populationyearbook2006s 167

OECD (2019). Economic surveys: China 2019. Paris: OECD Publishing. Retrieved from https://doi.org/10.1787/eco_surveys-chn-2019-en

Passport analysis (2018a). Top 5 countries with the largest labor force declines. Retrieved from: https://proxylibrary.hse.ru:3617/portal/analysis/tab

Passport analysis (2018b). Population change as a megatrend driver. Retrieved from: https://proxylibrary.hse.ru:3617/portal/Analysis/Tab

Passport analysis (2019a). Nearing the urban billion: How urbanization is changing the face of China's cities. Retrieved from: https://proxylibrary.hse.ru:3617/portal/Analysis/Tab

Passport analysis (2019b). China in 2030: the future demographic. Retrieved from: https://proxylibrary.hse.ru:3617/portal/Analysis/Tab 
Passport statistics (2019). China population. Retrieved from: https://proxylibrary.hse.ru:3617/portal/statisticsevolution/index

United Nations, Department of Economic and Social Affairs, Population Division (2019). World Population Prospects 2019: Data Booklet (ST/ESA/SER.A/424). 


\title{
THE DEMOGRAPHIC FUTURE OF CHINA
}

\section{YULIA SELIVERSTOVA}

\begin{abstract}
The article presents a forecast of the demographic situation in China until 2050. The author analyzes current demographic changes such as the rapid aging of the population, decrease in fertility, reduction in the workforce, gender imbalance, spread of nuclear families, internal labor migration and growth of urbanization. The article shows that the reason for the existing social problems lies in birth control. Family planning policy was actively promoted for 35 years, until 2016. During this time, the spread of small families, partly childless behavior and modern consumer society changed the traditional family and its functions. An analysis of existing forecasts shows that if the key parameters of demographic development are maintained, China's population will soon reach a maximum of 1.45 billion. Within 8 years the potential growth will be exhausted and there will occur a natural decline of the population. With the increasing numbers of older people and the growth of life expectancy, the working-age population will continue to shrink and the number of children under the age of 14 years will decrease even further. The demographic dividend for the PRC will be over. The economic slowdown will be accompanied by a significant burden on the social security, health care and city registration systems. In order to effectively counter the growing crisis, the government must focus more on solving the problems of rural residents, reforming the pension and health insurance systems, stimulating fertility and supporting families with children.
\end{abstract}

Key words: population of China, nuclear family, population aging, fertility decline, urbanization, labor migration, birth control policy, demographic dividend.

Yulia Seliverstova (yukupriyanova@hse.ru), NATional Research University Higher School of Economics, RUSSIA.

DATE RECEIVED : APRIL 2020.

\section{REFERENCES}

Akimov A.V. (2015). Prognoz chislennosti mirovogo naseleniya do 2050 g. i trudosberegayushchiye tekhnologii. Eastern Analytics, 5, 9-26. (In Russ.).

Antropov R.V., Sereda A.V. (2017). Pravo na trudovuyu pensiyu po starosti v sovremennom Kitaye: problemy realizatsii [The right to an old-age retirement pension in modern China: implementation challenges]. In Lavrov A.YU. (Ed.), Aktual'nyye problemy razvitiya KNR $v$ protsesse eye regionalizatsii i globalizatsii [Actual problems of the development of China in the process of its regionalization and globalization] (pp. 13-20). Chita: Zabaykal'skiy gosudarstvennyy universitet. (In Russ.).

Bazhenova E.S. (2010). 1300000. Naseleniye Kitaya: strategiya razvitiya i demograficheskoy politiki [Population of China: development strategy and population policy]. Moscow: Forum. (In Russ.).

Bazhenova E.S. (2018b). Sotsial'no-demograficheskoye razvitiye KNR [Social and demographic development of the PRC]. In Luzyanin S.G. (Ed.), Kitayskaya Narodnaya Respublika: politika, ekonomika, kul'tura. 2017-2018 [People's Republic of China: Politics, Economics, Culture. 2017-2018] (pp. 109-119). Moscow: Izdatel'stvo «Forum». (In Russ.).

Bazhenova E.S. (2018a). Chinese Family in the Course of New Population Policy. In Ostrovsky A.V. (Ed.), 13-ya pyatiletka (2016- 2020 gg.) - vazhneyshiy etap postroyeniya $v$ Kitaye obshchestva malogo blagodenstviya "syaokan" [13th Five-Year Plan (2016-2020) - The most 
important stage in building China's welfare society "Xiaokan"] (pp. 97-109). Moscow: FGBUN IDV RAN. (In Russ.).

Bazhenova E.S. (2019). China's population: New trends in the era of modernization and economic reforms. Far Eastern Affairs, 5 (1), 101-111. (In Russ.). DOI: https://doi.org/10.31857/S013128120007131-5

Fahrislamova R.T. (2015). Low fertility: theories and approaches for explanation. Bulletin of the South Russian State Technical University. Socio-economic Sciences, 2, 101-109. (In Russ.).

Fang Lieming (2019). Will China's "Two-child in one family" policy to spur population growth work? Population and Economics, 3 (2), 36-44.

DOI: https://doi.org/10.3897/popecon.3.e37962

Kalabikhina I., Shatalova E., Fang Lieming (2020). Demographic situation in China: convergence or divergence? BRICS Journal of Economics, 1 (1), 81-101. DOI: http://doi.org/10.38050/2712-7508-2020-6

Kireev A.A. (2015). The changes in demographic policy of China. Scientific Notes of Komsomolsk-on-Amur State Technical University, 2(2), 15-17. (In Russ.).

Kireyev A.A. et. al. (2011). Sovremennyy Kitay. Sotsial'no-ekonomicheskoye razvitiye, natsional'naya politika, etnopsikhologiya [Modern China. Socio-economic development, national policy, ethnopsychology]. Moscow: URSS. (In Russ.).

Korotaev A.V., Zinkina Yu.V. (2014). Mathematical modeling and scenarious forecast of demographic future of PRC. Eastern Analytics, 4, 36-41. (In Russ.).

Li Wei (2003). Razvitiye naseleniya i semeyno-demograficheskaya politika v Kitaye i Rossii: Opyt sravnitel'nogo analiza [Population development, family and demographic policy in China and Russia: a comparative analysis]. Moscow: Maks Press. (In Russ.).

Lutz W., Skirbekk V., Testa M.R. (2006). The Low-Fertility Trap Hypothesis: Forces that May Lead to Further Postponement and Fewer Births in Europe. Vienna Yearbook of Population Research, 4. (Postponement of Childbearing in Europe), 167-192.

DOI:10.1553/populationyearbook2006s 167

Nazarova R.F., Serova V.D. (2010). Demograficheskaya politika KNR: istoriya i sovremennost' [Demographic policy of the PRC: history and modernity]. Vestnik Amurskogo gosudarstvennogo universiteta. Seriya: Gumanitarnyye nauki, 50, 42-49. (In Russ.).

OECD (2019). Economic surveys: China 2019. Paris: OECD Publishing. Retrieved from https://doi.org/10.1787/eco_surveys-chn-2019-en

Ostrovskij A.V. (2013). The Chinese economy in 2030: problems and prospects (How to treat the forecast of economic development of China made by the Center for the study of law in the country, Tsinghua University). In Doklady IDV RAN [Reports of the RAS IFES] (pp.2950). Moscow: FGBUN IDV RAN. (In Russ.)

Passport analysis (2018a). Top 5 countries with the largest labor force declines. Retrieved from: https://proxylibrary.hse.ru:3617/portal/analysis/tab

Passport analysis (2018b). Population change as a megatrend driver. Retrieved from https://proxylibrary.hse.ru:3617/portal/Analysis/Tab

Passport analysis (2019a). Nearing the urban billion: How urbanization is changing the face of China's cities. Retrieved from https://proxylibrary.hse.ru:3617/portal/Analysis/Tab

Passport analysis (2019b). China in 2030: the future demographic. Retrieved from: https://proxylibrary.hse.ru:3617/portal/Analysis/Tab 
Passport statistics (2019). China population. Retrieved from: https://proxylibrary.hse.ru:3617/portal/statisticsevolution/index

Pochagina O.V. (2016). Deformation of family ties as a threat to China's social stability. In Lavrov A.YU. (Ed.), Aktual'nyye problemy razvitiya KNR v protsesse eye regionalizatsii $i$ globalizatsii [Actual problems of the development of China in the process of regionalization and globalization] (pp. 181-193). Chita: Zabaykal'skiy gosudarstvennyy universitet. (In Russ.).

Ponkratova L.A., Trakova E.B. (2014). Internal migration in China: what the 2010th population census showed. In Ponkratova L.A., Zabiyako A.A. (Eds.), Russia and China: a new vector of development of social and economic cooperation (pp. 109-116). Blagoveschensk: Amurskiy gosudarstvennyy universitet (In Russ.).

Roslyakov A.A., Startseva S.V. (2019) Sravnitel'no-pravovoy analiz pensionnykh sistem RF i KNR. Modern science, 12 (1), 388-391. (In Russ.).

Shcherbakova Ye.M. (2014). Demograficheskaya nagruzka snizilas' do minimal'nogo urovnya, no v blizhayshiye gody nachnet vozrastat'. Demoskop Weekly, 601-602. (In Russ.). Retrieved from: http://www.demoscope.ru/weekly/2014/0601/barom04.php

Shcherbakova Ye.M. (2019). Naseleniye mira po otsenkam OON peresmotra 2019 goda. Demoskop Weekly, 821-822. (In Russ.). Retrieved from: http://www.demoscope.ru/weekly/2019/0821/barom06.php

Sivintseva O.V. (2019). Pronatalist turn in China: a return to traditional family values or a new reality? Bulletin of Perm University. Political Science, 13, 3, 54-67. (In Russ.). DOI: https://doi.org/10.17072/2218-1067-2019-3-54-67

Sun $\mathrm{Fu}$ (2017). Economic and legal basis of development of Chinese pension system. Economics: Yesterday, Today and Tomorrow, 7(2A), 171-185. (In Russ.)

United Nations, Department of Economic and Social Affairs, Population Division (2019). World Population Prospects 2019: Data Booklet (ST/ESA/SER.A/424).

Veselova L.S. (2018). Changes in women's status in modern China: new challenges and opportunities. Uchenye Zapiski Kazanskogo Universiteta. Seriya Gumanitarnye Nauki [Scientific notes of Kazan University. Humanities Series], 160(6), 1455-1465. (In Russ.).

Vinogradov A.V. et. al. (2014). Stsenarii razvitiya Kitay. do 2050 g. [Scenarios for China's development until 2050]. Eastern Analytics, 4, 11-15. (In Russ.).

Wang Jingting (2019). The budget of the elderly in China: the strategy of its creation. Society: Sociology, Psychology, Pedagogics, 6(62), 61-66. (In Russ.). DOI: https://doi.org/10.24158/spp.2019.6.9

Wang Lili (2020). Ways and forms of improving the migration of peasants to cities in China. Medicine. Sociology. Philosophy. Applied research, 2, 34-38. (In Russ.).

Wu Yao (2015). Social integration of Chinese internal migrants: the living conditions of domestic migrants (agricultural to nonagricultural) and migrant workers. Moscow State University Bulletin. Series 18. Sociology and Political Science, 4, 235-240. (In Russ.).

Xu Yanli (2017). Demographic aspects of development of pensions system in China. Labour and Social Relations, 3, 76-83. (In Russ.).

Yin Shasha (2019). Children of rural migrants in China: research on the socialization problems. Obshchestvo: Sotsiologiya, Psikhologiya, Pedagogika [Society: sociology, psychology, pedagogy], 2 (58), 50-54. (In Russ.). DOI: 10.24158/spp.2019.2.8 